\title{
The Impact of Commitment Time Sharing Companies by Applying the Standards of Corporate Governance in Creating Sustainable Employment Opportunities in Jordan
}

\author{
Ahmed Fawaz Malkawi ${ }^{1} \&$ Hamzeh Al Hawamdeh ${ }^{2}$ \\ ${ }^{1}$ Department of Administrative Sciences, Jerash University, Jordan \\ Correspondence: Ahmed Fawaz Malkawi, Department of Administrative Sciences, Jerash University, Jordan. \\ E-mail: art.malka@yahoo.com
}

Received: April 1, 2018

doi:10.5539/ijbm.v13n7p230
Accepted: May 13, 2018

Online Published: June 15, 2018

URL: https://doi.org/10.5539/ijbm.v13n7p230

\begin{abstract}
The study aimed to introduce governance and its associated concepts, and the reality of the application of the concept of governance in the time- sharing companies and their impact on the creation of permanent jobs, and defined the time sharing companies and the laws governing them, and addressed the process for these companies and the statement of practice for the concept of governance and its impact on the creation of permanent jobs. To achieve the objectives and testing of hypotheses a questionnaire was developed especially for the collection of data from a study sample, the number of questionnaires analyzed are (87), By using appropriate statistical tests, results of the study showed that A set of results showed a huge impact of commitment of time sharing companies which applies corporate governance in creating sustainable employment opportunities in Jordan in the four areas related to the study questions, there is a statistically significant difference between the cumulative rates of all sections which relates to the personal variables of the sample of respondents in the study population. The study has provided a set of recommendations which includes encouraging this investment sector by the concerned authorities because of its great contribution to the creation of permanent jobs and consolidate the values and principles of governance in this type of companies (time-sharing companies) because of its strong impact in the creation of permanent jobs.
\end{abstract}

Keywords: time-sharing companies, governance, creation of employment opportunities, Jordan

\section{Introduction}

Recently, in Jordan 's tourism sector, a modern concept of time - sharing or the so - called ( Time share ) showed up, and an emerged group of the companies which practice selling time shares by ownership, and companies practicing marketing this type of product, there have been varied views on the usefulness of this system or activity or even if it could be called the new commercial contract or tourism, about its legality, and the extent of use and whether achieved success on the level of trade and tourism in the creation of permanent jobs in these sectors. Under the corporate governance followed in different types of companies the study will address the subject of corporate governance specifically in Time - sharing and the extent of the impact of it to create permanent jobs in Jordan.

\subsection{Study Problem}

The theme of governance stems from the use of the concepts of transparency, integrity, participation, clarity and application of laws, regulations and instructions, accountability and hence the problem of the study is determined in the realization of the impact of the application of this concept In the time - sharing companies adapted by tourism companies recently in the creation of permanent jobs in Jordan.

\subsection{Study Questions}

1) What is the effect of an effective framework for governance in time - sharing companies in contribution to the creation of permanent jobs?

2) What is the effect of disclosure and transparency of systems in time - sharing companies in contribution to creating permanent jobs?

3) What is the effect of the availability of regulations to control property system in time - sharing companies in 
contribution to the creation of permanent jobs?

4) What is the impact of a system which ensures that the rights of clients in time - sharing companies in contribution to the creation of permanent jobs?

\subsection{Study Significance}

The study draws its importance from both sides, along with related to the concept of governance and its impact on the financial and administrative reform and rationalization of decisions at different administrative levels in companies as a prerequisite to avoid a faltering and crises and a new type of new companies which made a significant contribution to the revitalization of tourism and created employment opportunities in various areas, namely, time - sharing companies.

\subsection{Objectives of the Study}

This study aims to introduce the corporate governance and its associated concepts, and the statement of the reality of the application of the concept of governance in the time sharing companies and their impact on the creation of permanent jobs, and the definition of companies sharing the time and the laws governing them, the study addressed the process of these companies and the statement of practical reality for the concept of governance and its impact on the creation of permanent jobs.

\subsection{Hypotheses}

1) There is a significant effect with significant statistic for the presence of governance systems in the time sharing companies which contributes to the creation of permanent jobs.

2) There is a statistically significant effect to the disclosure and transparency in the time sharing companies which contributes to the creation of a permanent employment system.

3) There is a significant impact with statistical significance to the availability of regulations to control property in the time - sharing companies which contributes to the creation of permanent jobs.

4) There is a significant effect with significant statistics of adapting corporate governance system that ensures the rights of clients in the time - sharing companies which contributes to the creation of permanentjobs.

\subsection{The Study Methodology and Its Tool}

The researcher has used the survey method, and has been referred to the most important literary references in the field of theoretical study related to the concept of corporate governance. Beside the use of the questionnaire, data collection and analysis to extract the results of the study.

\subsection{Authenticity of the Tool and Its Stability}

The researcher has introduced the questionnaire on a group of specialists in order to ensure the sincerity of the survey and its ability to achieve the objectives of the research which showed based on their point of view the sincerity of its content. To find out the extent of stability Cronbach's alpha coefficient was used, the analysis of the alpha Cronbach coefficient shows the consistency and coherence between the internal content of the statements, explained in the table (1).

Table 1. Values of Kronbach alpha

\begin{tabular}{llll}
\hline Number & Paragraphs & Phrase Numbers & Alpha value \\
\hline $\mathbf{1}$ & Availability of an effective framework & $1-11$ & 0.859 \\
$\mathbf{2}$ & Availability of disclosure and transparency systems & $11-20$ & 0.897 \\
$\mathbf{3}$ & Availability of regulatory rules for controlling the ownership system & $21-29$ & 0.8134 \\
$\mathbf{4}$ & Availability of a system that guarantees the rights of customers & $30-39$ & 0.926 \\
\hline
\end{tabular}

\subsection{Study Sample}

The study population of the companies registered in the Ministry of Industry and Trade - Companies Control Department in Jordan are (12) distributed as follows: 1. the time - sharing (1), 2. Time and tourist vacations sharing (6) Marketing participation time system (5), the distribution of the questionnaire on the employees will be involving various levels of management.

\section{Previous Studies}

Study (Balloot, 2015) entitled "The effects of time - sharing contract." The study aimed to indicate what time - 
sharing contract, the characteristics of the pillars of the contract as a contract and a novel statement implications and the penalty resulting from the breach of contract, the study had concluded these results:

The time - sharing contract is a contract that ensure the transfer of ownership of a stake in a tourist unit for an amount paid by the beneficiary, which has appeared in the United Kingdom in Scotland specifically then in other countries and it has been legalised in some countries and some countries did not organise it legally.

The time - sharing contract has similarity with the general contracts. The most prominent recommendations were: The need to organize a time - sharing contract in a separate law and the need to organize a time - sharing contract in accordance with the rules of the Jordanian Civil Code.

Study (Alsartawy, 2015) entitled "The impact of corporate governance on the performance of listed companies in the stock markets in the GCC," the study summed up the problem in the answer of questions related to the level of governance institutional and its effect on the improvement of performance on Index in companies listed at markets in GCC countries. . The study aimed to demonstrate the impact of governance on the institutional performance as a main target falls below it a number of sub - objectives of which determine the level of governance and the extent of the disparity in the level of application of governance and to recognize the impact of the institutional governance in improving performance indicators, and the performance of the stock in the companies. The study reached a number of results, notably the existence of a sufficient level of the degree of commitment to the principles of corporate governance, and that corporate governance is not only impact the company's financial performance, but also affects the operational performance.

Study (AL Sawy, 2013) entitled "Time- Share between the Islamic perspective and contemporary application", the study was based on the descriptive approach where the papers which presented for the symposium dealt with, as well as discussions which dart about the system and all its details, everybody concluded that Islam encourages the system considering it as a part of tourism activity, taking into account the sharia controls for any economic activity, the most important recommendations of the symposium included the declaration of the interest of Islam that tourism is a humanitarian activity and the importance of reaching a fully legal legislation to organize this activity, and there has to be controls for marketing destinations and their campaigns which targets beneficiaries.

\section{Theoretical Framework}

\subsection{Introduction}

Despite the modern use of the term but its appearance is due to a long time, theoretical and historical premise of corporate governance relates to the theory (Berle \& Means, 1932), who noticed that there is a separation between the ownership of the company's capital and process control and supervision within the corporate process that is due to the appearance of the Americans Agency Theory, And this separation has implications on the level of performance of the company, then came the role of Americans Jensen and Meckling, the Nobel Prize winners of the economy, who were interested in the concept of corporate governance and highlighted the importance of reducing or minimizing the problems that may arise from the separation of property and management represented by the theory of the Agency, in 1976 they represented (a famous relationship Agency theory) as a whereby the main person (the shareholder) asks someone else's "worker" to substitute for some tasks (Ismail, 2010)

\subsection{The First Section: Governance}

\subsubsection{Definition of Governance}

The Organization of Economic Cooperation and Development has defined governance by: a system that adjusts and directs the work of companies through Characterization and clarifying the rights and duties between the various parties in the companies' board of directors, employees, dealers and shareholders ".And sets necessary rules to make decisions concerning the management of the company and the goals and the means available to achieve the objectives of the company and monitor its performance and reliance on institutional work and procedures through the development of self - systems management, direction and control (Hammadi, 2012).

Corporate governance characteristics, includes:

- Discipline: Any ethical and correction of behaviour.

- Transparency: A true picture of everything that happens.

- Independence: There are no unnecessary effects and pressures to work. (Abdullah, 2010).

Governance objectives:

- The goals of governance at the level of the national economy:

- Increasing confidence in the national economy. 
- Maintaining the Minority Rights of "Minor Shareholders"

- Private sector growth and support of its competitiveness.

- Create new job opportunities. (Adel 2011).

Governance Standards

The Organization for Economic Cooperation and Development has reached the following standards principles in the field of corporate governance:

- The availability of an effective framework for corporate governance: The corporate governance structure should improve the transparency and efficiency of securities markets and be consistent with the role of the law and clearly define the division of responsibilities between the various bodies responsible for supervision and control and enforcement of the law.

- Protection of Shareholders' Equity: the rules of corporate governance practice must protect the equity and access to information on the company periodically, and participation and voting in the meetings of the general assembly of shareholders.

- Disclosure and transparency: The strong disclosure systems are considered as a key feature of follow - up based on corporate methods to market forces and occupies great importance in helping shareholders to exercise their rights, the proper disclosure is a powerful tool to influence corporate behaviour and to protect investors and to attract capital and maintain confidence in companies (Alqashi 2011).

\subsection{The Second Section: Time Sharing}

\subsubsection{Definition of Time-Sharing}

Such a contract is also calleda label "owning a holiday which is known as an economic unit that is owned in tourist place by several people for subscription, but each of them has the right to use this unit for a short time, usually a week or two weeks every year (Wikipedia, 2006).

\subsubsection{History of Time-Sharing:}

Sharing time Began spreading in Europe and other Western countries in the early sixties, after the raise of the prices of the buildings suitable for vacations, therefore it has become very difficult to find a place to spend a holiday, and the solution was to sella large number of tourist units for buyers so that each of them can benefit from the tourist unit during the a specific time and in a different way from the other buyer (Mahasneh, 2006). The time - sharing structured legislation in developed countries like the United States, Britain and other European countries, and is structured in most Arab countries and in Jordan specifically, which raises some sort of difficulty in controlling and regulating this type of contract. Because of the lack of legislation in Jordan which governs this contract the preparation of this research has been guided by the Supreme Council for Tourism decisions issued in 1999 regarding the sharing of time and published in the Official newspaper 4362 dated July 17, 1999. (Abdul Qadir, 1999)

The fundamental difference between the purchase and rental of time is that the first is similar to those who buy a real and tangible property and the existing material, regardless of what occurs to the change of tourist management unit. The second is that someone who buys a contractual promise from the management of the tourist resort to obtain the benefit. As a result, the buyer's benefit and his use of the tourism unit depend on whether it is satisfactory to him or not. (Emerson, 2005).

\subsubsection{Sharing-Time Types}

The types of time sharing in the contract are divided into two parts: the first: hard time, and in such a case it uses a common tourism unit at the same time every year for the duration of the contract and for a specific period which often can be two weeks. Second: Floating time, and in this case, the joint reserves the right to change the time of the use of tourist unit every year and is committed to a specific date every year, but it is committed to a particular season every year which runs from three to four months. We Can also talk about a third type of time - sharing, which is called time revolving, so that time is different every year and spins on subscribers so try each subscriber Rotating Every time of the year in the course of his holiday and not deprived of a certain time and in accordance with a certain order (Atwi, 2004).

\section{Statistical Processing}

\subsection{The study Sample}

The study sample consisted of 87 individuals, Table 1 shows the distribution of the sample depending on the 
personal and functional variables.

Table 1. Distribution of sample members according to personal and functional variables

\begin{tabular}{llll}
\hline variable & Category & Repetition & percentage \\
\hline \multirow{4}{*}{ Age } & $20-30$ & 25 & 28.7 \\
& $31-40$ & 23 & 26.4 \\
& $41-50$ & 27 & 31.0 \\
& $51-60$ & 12 & 13.8 \\
Total & $\mathbf{8 7}$ & $\mathbf{1 0 0 . 0}$ \\
diploma & 24 & 27.6 \\
Qualification & Bachelor & 48 & 55.2 \\
& M.A. & 12 & 13.8 \\
& Ph.D. & 3 & 3.4 \\
Total & $\mathbf{8 7}$ & $\mathbf{1 0 0 . 0}$ \\
Career Level & 24 & 27.6 \\
& Director & 17 & 19.5 \\
& Assistant Director & 23 & 26.4 \\
& Head of the Department & 23 & 26.4 \\
& Executive Officer & $\mathbf{8 7}$ & $\mathbf{1 0 0 . 0}$ \\
Total & 19 & 21.8 \\
Experience in years & Less than 5 & 29 & 33.3 \\
& $6-10$ & 18 & 20.7 \\
& $11-15$ & 21 & 24.1 \\
& $16-20$ & $\mathbf{8 7}$ & $\mathbf{1 0 0 . 0}$ \\
\hline
\end{tabular}

Table (1) shows the following:

For the variable age, it shows that those aged between (41-50) are the top in frequency, which equals to (27) and represents $(31.0 \%)$, while those aged between (51-60) are the least frequent, which count (12) and represents $(13.8 \%)$.

For scientific qualification variable, it shows that the bachelor are the highest, which counts (48) and represents (55.2\%), while the doctoral are least frequent, which counts (3) and represents (3.4\%).

For the variable career level, the head director is the highest, which counts (24) and represents $(27.6 \%)$, while the assistant manager is the least frequent, which counts (17) and represents (19.5\%).

For the variable years of experiences, it shows that those whohas an experience between (6-10) are the highest, which counts (29) and represents (33.3\%), while 11-15 are the least frequent, which counts (18) and represents $(20.7 \%)$.

\subsection{Correction of Scale}

The questionnaire in its finalized Form has included (38) paragraphs, where the researcher used Likert scale in order to gauge the views of the study sample individuals, strongly agreewas rated (5), agree was rated (4), neutral was rated (3), disagree was rated (2), and strongly disagree was rated ( 1), by placing a signal $(\sqrt{ })$ in front of the answer that reflects the degree of consent, the following classification of judgment was relying on the arithmetic averages as follows:

- Less than 2.33 low.

- From 2.34 to 3.66 average.

- From 3.67 to 5.00 high.

\subsection{Study Questions Testing}

To answer the study questions, the following statistical approaches were used through the statistical packages of the program (SPSS):

- Frequency and percentages of personal and functional variables of the sample of the study.

- Arithmetic averages and standard deviations for the answers of the study sample in all areas of the study tool. 
- (ANOVA) Test to detect the differences of the responses of the members of the study sample for the fields of the total study tool according to the personal variables.

- (MANOVA ) Test to detect differences between the arithmetic averages study areas depending on the personal and functional variables.

\section{Results}

This chapter includes the results of the study aimed at identifying the impact of time-sharing companies on applying the standards of governance in creating permanent jobs in Jordan. The results will be presented based on the study's questions.

\subsection{Analysis of the Results of the Study Questions}

\subsubsection{The First Question to Study}

What is the impact of applying the standards of governance in time-sharing companies on creating permanent jobs in Jordan?

To answer this question, the averages and standard deviations of the paragraphs with each field of study have been calculated, and the tables below illustrate the results.

The first area: What is the effect of providing an effective framework for governance in time - sharing companies which will contribute to the creation of permanent jobs?

Table 2. Arithmetic averages and standard deviations of field and field paragraphs "What are the effects of providing an effective framework for governance in time - sharing companies which will contribute to the creation of permanent jobs "as a whole $(\mathrm{n}=87)$

\begin{tabular}{|c|c|c|c|c|c|}
\hline Number & Paragraph & SMA & $\begin{array}{l}\text { Standard } \\
\text { Deviation }\end{array}$ & Rank & Class \\
\hline 1 & $\begin{array}{l}\text { The company maintains a governance guide and regulations that reflect the company's } \\
\text { desire to follow the latest sound methods to improve performance, thus contributing to } \\
\text { the creation of permanent jobs opportunities. }\end{array}$ & 4.90 & 0.31 & 2 & High \\
\hline 2 & $\begin{array}{l}\text { The company has a governance regulation that is flexible enough to suit the different } \\
\text { needs of customers and does not interfere with the company's interest, which } \\
\text { reinforces investment in this field and opportunities. }\end{array}$ & 4.93 & 0.25 & 1 & High \\
\hline 3 & $\begin{array}{l}\text { The company has a set of policies and regulations that comply with the legal and } \\
\text { legislative requirements that affect the } 3 \text { governance practices, which reinforces } \\
\text { investment in this field and contributes to the creation of permanent jobs. }\end{array}$ & 4.76 & 0.43 & 4 & High \\
\hline 4 & $\begin{array}{l}\text { The requirements of governance are transparent, fair and impartial between the board } \\
\text { of directors of the company and } 4 \quad \text { customers, thus enhancing trust between them } \\
\text { and contributing to the creation of permanent jobs. }\end{array}$ & 4.52 & 0.50 & 9 & High \\
\hline 5 & $\begin{array}{l}\text { The distribution of supervisory and executive responsibilities and the application of } \\
\text { laws between different entities help to effectively implement the corporate governance } \\
\text { framework, thus contributing to the creation of permanent employment opportunities. }\end{array}$ & 4.62 & 0.49 & 6 & High \\
\hline 6 & $\begin{array}{l}\text { It has a transparent governance structure and achieves the basic public interest which } \\
\text { increases customer confidence in the quality of the company's performance and } \\
\text { contributes to the creation of permanent jobs. }\end{array}$ & 4.79 & 0.41 & 3 & High \\
\hline 7 & $\begin{array}{l}\text { The presence of a committee within the Board of Directors to monitor and measure the } \\
\text { efficiency of the company's management application of the principles of governance } \\
\text { increases the confidence of customers in the effectiveness of the governance } \\
\text { framework and positively reflects on the creation of permanent jobs. }\end{array}$ & 4.72 & 0.45 & 5 & High \\
\hline 8 & $\begin{array}{l}\text { The existence of periodic meetings of the Committee to study the modern } 8 \\
\text { requirements of governance affects the creation of permanent jobs. }\end{array}$ & 4.45 & 0.50 & 10 & High \\
\hline 9 & $\begin{array}{l}\text { The services provided by corporate governance principles are characterized by better } \\
\text { quality performance than those that are not applied to the principles of governance, } \\
\text { thus contributing to the creation of permanent employment opportunities. }\end{array}$ & 4.55 & 0.50 & 8 & High \\
\hline \multirow[t]{2}{*}{10} & $\begin{array}{l}\text { The regulations governing time-sharing companies in terms of regulations and } \\
\text { standards are consistent with the regulations of companies of another }\end{array}$ & 4.62 & 0.49 & 6 & High \\
\hline & $\begin{array}{l}\text { The impact of an effective framework for the governance of time-sharing companies } \\
\text { contributes to the creation of permanent employment opportunities" as a whole }\end{array}$ & 4.69 & 0.21 & - & High \\
\hline
\end{tabular}

Table 2 shows that the arithmetic averages ranged between (4.45 - 4.93), where the paragraph No. (2) which states that "the company has a list of corporate governance are flexible enough to suit the different needs of the customers and does not have a conflict with the interest of the company, which raises investment in this sector and contribute to the creation of permanent jobs in the first place and in an arithmetic mean (4.93) and a high degree, paragraph (8) 
was ranked the last which states that "the existence of periodic committee meetings to study the modern requirements of governance affect the creation of permanent jobs. "with an arithmetic mean ( 4:45) and a high degree, and the arithmetic average of the field, "what effect provides by an effective framework for time sharing governance which contributes to the creation of permanent jobs "as a whole (4.69) and high degree, which means having a significant impact to the availability of Providing an effective framework for the governance of time-sharing companies that contributes to the creation of permanent employment opportunities Which supports the first hypothesis.

The second area: What is the impact of the availability of disclosure systems and transparency in time sharing companies that contribute to the creation of permanent jobs?

Table 3. Arithmetic averages and standard deviations of field and field paragraphs "What is the impact of the availability of disclosure systems and transparency in time-sharing companies that contribute to the creation of permanent jobs? "As a whole $(\mathrm{n}=87)$

\begin{tabular}{|c|c|c|c|c|}
\hline \multicolumn{2}{|c|}{ NumberParagraph } & $\begin{array}{r}\text { SMAstandard } \\
\text { deviation }\end{array}$ & \multicolumn{2}{|c|}{ RankClass } \\
\hline 1 & $\begin{array}{l}\text { There is a consensus between the ownership contract in the time-sharing companies and the laws } 4.52 \\
\text { relating to sale or leasing, which facilitates the process of litigation between the parties to the } \\
\text { dispute. }\end{array}$ & 0.50 & 10 & High \\
\hline 2 & $\begin{array}{l}\text { The ability of the Marketing representative in attraction and persuasion makes the customer enters } 4.62 \\
\text { into a contract by his will and without prejudice to the contract in terms of satisfaction. }\end{array}$ & 0.49 & 7 & High \\
\hline
\end{tabular}
process easy and accessible.

$4 \quad$ Legal texts that explicit provisions of this contract controlled by Jordanian law considers making it4.76 0:43 easier to resolve disputes between contractors.

5 The implications of the conclusion of the contract for the owner and the customer is considered a4.90 0:31 positive and can check the interest of The two sides in a balanced manner.

6 Time sharing Contract includes all the issues relating to the rights and obligations of the parties to4.72 0.45 the contract, which makes it easier for the legislature of conflict resolution.

7 Contract illustrates the concept of partnership in the ownership in terms of succession and rotation4:55 0.50 to make use of a single place.

8 Naming the contract linked to the legal adaptation of the contract in terms of long- term rent or sale4.62 0.49 with retail property or permanent ownership.

9 The provisions of the contract awarding the Jordanian legislator the ability to treat imbalances4.69 0:47 resulting from weak field experience resulting from mutual misunderstanding between the parties.

10 There is consensus between the property held in the sharing of time and law firms relating to the sale4.76 0:43 or lease which facilitates the process of litigation between the conflicting parties.

The impact of the availability and transparency of disclosure systems in time - sharing companies4.69 0.22 will contribute to the creation of permanent jobs " as a whole

Table 3 shows that the arithmetic averages ranged between (4.52 - 4.90), where the paragraph (5) which states that "the effects of the conclusion of the contract for the owner and the customer is considered a positive and mutual benefit achieved in a balanced manner." Ranked first with a mean (4.90) and a high degree, and paragraph (1) was ranked last which states that "there is consensus between the property held in the sharing of time and law firms relating to the sale or lease which facilitates litigation between the conflicting parties to the process." An arithmetic mean (4.52) and a high degree, and the arithmetic average of the field, "the impact of the availability and transparency of disclosure systems in time - sharing companies will contribute to the creation of permanent jobs?" As a whole (4.69) and high degree,which means having a significant impact to the availability of disclosure and transparency of systems in time - sharing companies which will contribute to the creation of permanent jobs, which supports the validity of the second hypothesis.

The third area: What is the impact of the availability of regulations to control property system in time-sharing companies which contribute to the creation of permanent jobs? 
Table 4. Arithmetic averages and standard deviations of the paragraphs of the field and the field following the availability of the rules governing property system to adjust the time-sharing companies which contributes to the creation of permanent jobs "As a whole $(\mathrm{n}=87)$

\begin{tabular}{|c|c|c|c|c|c|}
\hline Number & Paragraph & SMA & $\begin{array}{l}\text { standard } \\
\text { deviation }\end{array}$ & Rank & Class \\
\hline 1 & $\begin{array}{l}\text { There is consensus between the property held in the sharing of time and } \\
\text { law firms relating to the sale or lease which facilitates the process of } \\
\text { litigation between the conflicting parties. }\end{array}$ & 4.66 & 0.48 & 7 & High \\
\hline 2 & $\begin{array}{l}\text { The ability of Marketing representative for the attraction and persuasion } \\
\text { makes the customer enters into a contract by his will and without prejudice } \\
\text { to the contract in terms of satisfaction. }\end{array}$ & 4.48 & 0.50 & 9 & High \\
\hline 3 & $\begin{array}{l}\text { The nature of the sharing of time and the idea underlying the contract } \\
\text { clearly making the contracting process easy and accessible. }\end{array}$ & 4.59 & 0.50 & 8 & High \\
\hline 4 & $\begin{array}{l}\text { Legal texts that explicit provisions of this contract controlled by Jordanian } \\
\text { law considers making it easier to resolve between contractors. }\end{array}$ & 4.76 & $0: 43$ & 3 & High \\
\hline 5 & $\begin{array}{l}\text { The conclusion of The implications of the contract for the owner and the } \\
\text { customer is considered positive and can check the interest of The two } \\
\text { sides in a balanced manner. }\end{array}$ & 4.76 & $0: 43$ & 3 & High \\
\hline 6 & $\begin{array}{l}\text { Time sharing Contract includes all the issues relating to the rights and } \\
\text { obligations of the parties of the contract, which makes it easier for the } \\
\text { legislature for conflict resolution. }\end{array}$ & 4.86 & 0.35 & 1 & High \\
\hline 7 & $\begin{array}{l}\text { The concept of contract partnership in the ownership and the use of It } \\
\text { illustrates the succession and rotation to make use of a single place. }\end{array}$ & 4.79 & 0.49 & 2 & High \\
\hline 8 & $\begin{array}{l}\text { Naming the contract is linked to the legal adaptation of the contract in } \\
\text { terms of long-term rent or sale with retail property or permanent } \\
\text { ownership. }\end{array}$ & 4.72 & 0.45 & 5 & High \\
\hline 9 & $\begin{array}{l}\text { The provisions of the contract awarded to the Jordanian legislator can } \\
\text { enhance the ability to treat imbalances resulting from weak field } \\
\text { experience resulting from mutual misunderstanding between the parties. }\end{array}$ & 4.69 & $0: 47$ & 6 & High \\
\hline \multicolumn{2}{|c|}{$\begin{array}{l}\text { "The effect of the availability of regulations to control property system in time - } \\
\text { sharing companies contribute to the creation of permanent jobs " As a whole }\end{array}$} & 4.70 & 0.23 & - & High \\
\hline
\end{tabular}

Table 4 shows that the arithmetic averages ranged between ( 4.48 - 4.86 ), where the paragraph No. 6 , which states, " a sharing time contract includes all issues relating to the rights and obligations of the parties of the contract, which makes it easier for the legislature for conflict resolution" in first place with an average (4.86) and a high degree, and paragraph (2)ranked last" the ability of the marketing representative for the attraction and persuasion makes the customer enters by his will and without prejudice to the contract in terms of satisfaction" with a mean ( 4.48 ) and a high degree, and the average arithmetic domain "what effect the availability of regulations to control property system in time - sharing companies which contributes to the creation of Permanent jobs? " As a whole (4.70) and high degree, which means a significant impact to the availability of regulations to control property system in time - sharing companies which contributes to the creation of permanent jobs, which supports the third hypothesis.

Fourth area: What is the effect provides by a system that guarantees the rights of clients in the time-sharing companies which will contribute to the creation of permanent jobs? 
Table 5. Arithmetic averages and standard deviations of the paragraphs of the field and the field,"What is the effect provides by a system that guarantees the rights of clients in the time - sharing companies which will contribute to the creation of permanent jobs?" As a whole $(n=87)$

\begin{tabular}{|c|c|c|c|c|c|}
\hline Number & Paragraph & SMA & $\begin{array}{l}\text { standard } \\
\text { deviation }\end{array}$ & Rank & Class \\
\hline 1 & $\begin{array}{l}\text { Respect for the rights of the owners of interests arising by law or as a result of } \\
\text { mutual agreements between the company and stakeholders, leading to raise the } \\
\text { level of expectation of creating permanent jobs. }\end{array}$ & $4: 55$ & 0.50 & 8 & High \\
\hline 2 & $\begin{array}{l}\text { Timely, relevant information of the stakeholders to carry out their } \\
\text { responsibilities will improve the level of expectation of creating permanent } \\
\text { jobs. }\end{array}$ & $4: 55$ & 0.50 & 8 & High \\
\hline 3 & $\begin{array}{l}\text { The ability of stakeholders, including employees and those who represent } \\
\text { them, for the delivery of any illegal acts to the Governing Council will improve } \\
\text { the level of expectation of creating permanent jobs. }\end{array}$ & 4.59 & 0.50 & 7 & High \\
\hline 4 & $\begin{array}{l}\text { The lack of exposure of stakeholders, including employees of any risk as a } \\
\text { result of any actions bring them illegal to the Governing Council raises the } \\
\text { level of expectation of creating permanent jobs. }\end{array}$ & 4.66 & 0.48 & 6 & High \\
\hline 5 & $\begin{array}{l}\text { An effective framework for addressing solvency and implementation of } \\
\text { creditors' rights mechanisms affect the good evaluation of the company's } \\
\text { performance which will improve the level of expectation of creating permanent } \\
\text { jobs. }\end{array}$ & 4.79 & 0.41 & 2 & High \\
\hline 6 & $\begin{array}{l}\text { The media stakeholders are sufficient about their rights and obligations when } \\
\text { association to work in the company which will improve the level of expectation } \\
\text { of creating permanent jobs. }\end{array}$ & 4.79 & 0.41 & 2 & High \\
\hline 7 & $\begin{array}{l}\text { The workers are trained adequately to deal with stakeholders which will } \\
\text { improve the level of expectation of creating permanent jobs. }\end{array}$ & 4.76 & 0.50 & 5 & High \\
\hline 8 & $\begin{array}{l}\text { The stakeholders' compensation in full, from any violation of their rights } \\
\text { increases confidence in the effective application of the framework of } \\
\text { governance, raising the level of expectation of creating permanent jobs. }\end{array}$ & 4.79 & 0.41 & 2 & High \\
\hline 9 & $\begin{array}{l}\text { The company organizing periodical meetings between staff and senior } \\
\text { management in order to take their proposals in the methods of implementation } \\
\text { of action to improve performance contributes to raising the level of expectation } \\
\text { of creating permanent jobs. }\end{array}$ & 4.83 & 0.38 & 1 & High \\
\hline \multicolumn{2}{|c|}{$\begin{array}{l}\text { "The impact of the system ensures that customers ' rights in time - sharing } \\
\text { companies will contribute to the creation of a permanent job offer" As a whole }\end{array}$} & 4.70 & 0.22 & - & High \\
\hline
\end{tabular}

Table 5 shows that the arithmetic averages ranged between ( 4.55 - 4.83 ), where paragraph (9), " the organization of the company's periodic meetings between staff and senior management in order to take their proposals in the methods of implementation of action to improve performance can contribute to raising the level of the expectation of creating permanent jobs, "ranked first with a mean (4.83) and a high degree, and paragraph (1) ranked last which states, " the respect for the owners of the emerging interests of rights under the law as a result of mutual agreements between the company and stakeholders, leading to raise the level of expectation of creating permanent job opportunities. " And paragraph (2) timely, relevant information of the stakeholders to carry out their responsibilities will improve the level of expectation of creating permanent jobs. "An arithmetic mean (4.55) and a high degree, and the arithmetic average of the field of "whateffect provides a system that guarantees the rights of clients in the time - sharing companies which will contribute to the creation of permanent jobs?" As a whole (4.70) and high degree,which means a significant effect to provide a system that guarantees the rights of clients in the time - sharing companies which will contribute to the creation of permanent jobs, which supports the fourth hypothesis.

\subsubsection{The Second Question of the Study}

Are there any statistical significant differences at the level of significance $(0.05 \geq \alpha)$ In the effect of 
commitmenting time sharing companies applying corporate governance standards in the creation of permanent jobs in Jordan due to variables (age, educational qualification, career level, experience)?

To answer this question, the application of multiple analysis of variance ( MANOVA ) To detect differences between arithmetic means in effect commitmenting the sharing of time companies applying the standards of governance in creating sustainable employment opportunities in Jordan, represented by ( the area provides an effective framework for corporate governance, the area of availability of disclosure and transparency of systems, the area of the availability of regulations to control property system, the area provides a system that guarantees the rights of clients ) according to the following variables (age, educational qualification, career level, experience) and the application of analysis of variance ( ANOVA) To detect differences between the averages in the measure " the impact of commitmenting the sharing of time companies applying the standards of governance in creating permanent jobs in Jordan " as a whole according to these variables (Appendix 1), The results showed the existence of apparent differences between the mean answers to the study sample individuals in all areas of impact time sharing companies whichcommitment the application of corporate governance standards in the creation of permanent jobs in Jordan due to variables (age, educational qualification, career level, experience), and to find out the statistical significance of those differences multiple analysis of variance (MANOVA) was applied, the impact of commitmenting time sharing companies applying the standards of governance in creating permanent jobs in Jordan, table 6 shows:

Table 6. The results of multiple analysis of variance ( MANOVA ) To detect differences in the effect of commitmenting the sharing of timecompanies applying corporate governance standards in the creation of permanent jobs in Jordan due to variables (age, educational qualification, career level, experience)

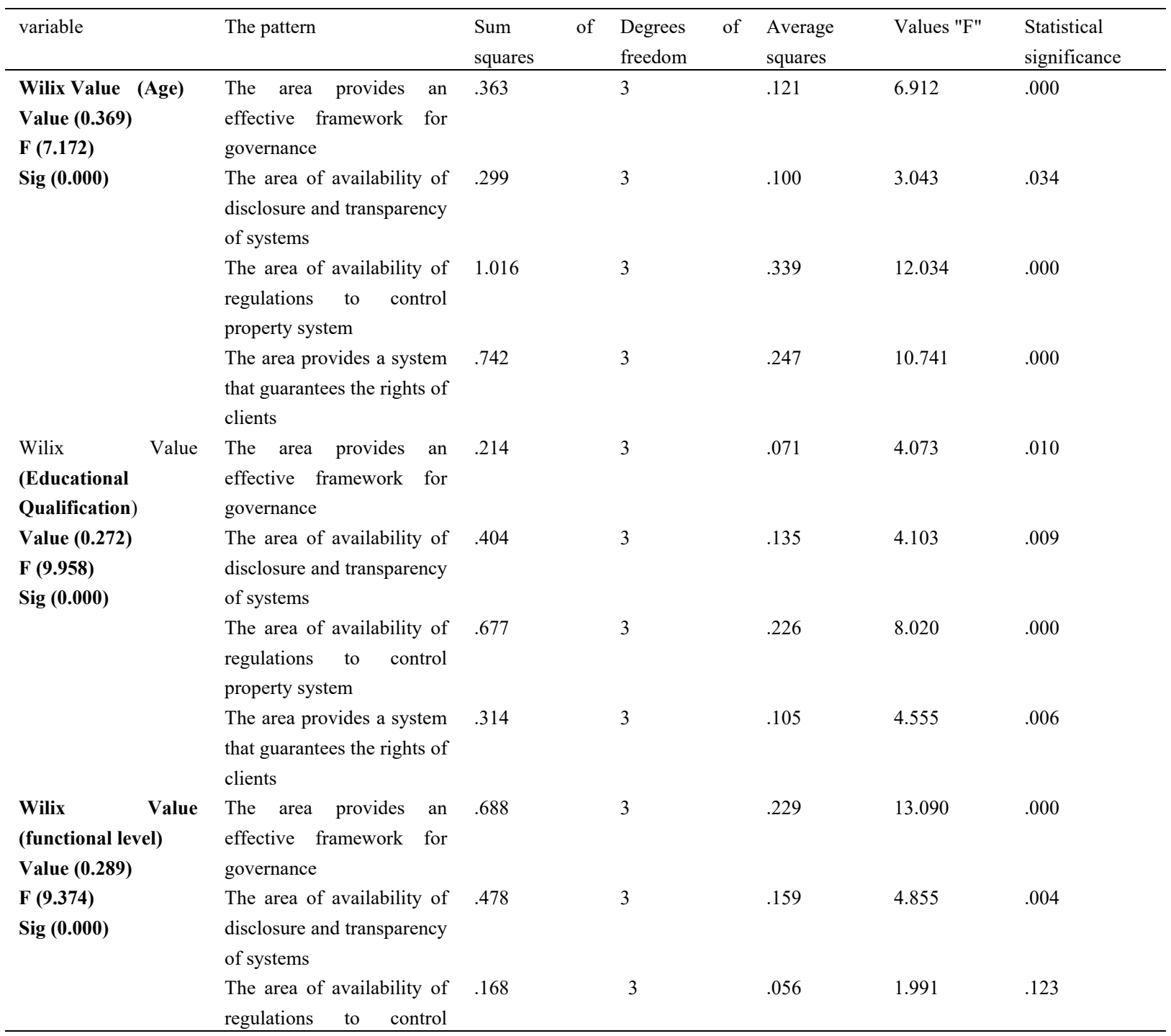




\begin{tabular}{|c|c|c|c|c|c|c|c|}
\hline \multirow[b]{3}{*}{$\begin{array}{l}\text { Wilix } \\
\text { (experience) } \\
\text { Value (0.349) }\end{array}$} & \multirow[b]{3}{*}{ Value } & \multicolumn{6}{|l|}{ property system } \\
\hline & & $\begin{array}{l}\text { The area provides a system } \\
\text { that guarantees the rights of } \\
\text { clients }\end{array}$ & .764 & 3 & .255 & 11.059 & .000 \\
\hline & & $\begin{array}{l}\text { The area provides an } \\
\text { effective framework for } \\
\text { governance }\end{array}$ & .318 & 3 & .106 & 6.051 & .001 \\
\hline \multirow{3}{*}{\multicolumn{2}{|c|}{$\begin{array}{l}\text { F (7.671) } \\
\text { Sig (0.000) }\end{array}$}} & $\begin{array}{l}\text { The area of availability of } \\
\text { disclosure and transparency } \\
\text { of systems }\end{array}$ & .369 & 3 & .123 & 3.750 & .014 \\
\hline & & $\begin{array}{l}\text { The area of availability of } \\
\text { regulations to control } \\
\text { property system }\end{array}$ & .277 & 3 & .092 & 3.280 & .026 \\
\hline & & $\begin{array}{l}\text { The area provides a system } \\
\text { that guarantees the rights of } \\
\text { clients }\end{array}$ & .241 & 3 & .080 & 3.497 & .020 \\
\hline \multirow{4}{*}{\multicolumn{2}{|c|}{ The error }} & $\begin{array}{l}\text { The area provides an } \\
\text { effective framework for } \\
\text { governance }\end{array}$ & 1.296 & 74 & .018 & & \\
\hline & & $\begin{array}{l}\text { The area of availability of } \\
\text { disclosure and transparency } \\
\text { of systems }\end{array}$ & 2.428 & 74 & .033 & & \\
\hline & & $\begin{array}{l}\text { The area of availability of } \\
\text { regulations to control } \\
\text { property system }\end{array}$ & 2.083 & 74 & .028 & & \\
\hline & & $\begin{array}{l}\text { The area provides a system } \\
\text { that guarantees the rights of } \\
\text { clients }\end{array}$ & 1.703 & 74 & .023 & & \\
\hline
\end{tabular}

Table (6) shows:

- No statistical significant differences at the level of significance ( $A \leq 0.05$ ) at All areas of the impact of commitmenting time sharing companies applying corporate governance standards in the creation of permanent jobs in Jordan due to variables (age, educational qualification, career level, experience), with the exception of (the area of the availability of regulations to control property system).

* To find out the differences in all areas of sites commitment the impact of time-sharing companies applying corporate governance standards in the creation of permanent jobs in Jordan, according to the variables (age, educational qualification, career level, experience), ( Scheffe ) test which shows Comparisons posteriori, Analysis has shown the following results (Appendix 2):

- Differences in the area "provide an effective framework for corporate governance according to the variable age" was between (20-30) and (51-60), and in favor of (51-60) where it reached the arithmetic average ( 4.93 ), while the arithmetic mean of the class (20-30) (4:55), did not show statistical significant differences between the other cumulative rates.

- Differences in the area of availability of disclosure and transparency of systems according to the variable age was between (31-40) and (51-60), and in favor of (51-60) where it reached the arithmetic average ( 4.83 ), while the arithmetic mean of the class (31-40) (4.67), no statistical significant differences appear between other cumulative rates.

- Differences in the area of availability of rules governing property system to adjust depending on the variable age was between (31-40) and (51-60), and in favor of (51-60) where it reached the arithmetic average(4.95), while the arithmetic average of the category (31-40) (4.56), no statistical significant differences appear between other cumulative rates.

- Differences in the area provide a system that guarantees the rights of clients depending on the variable age was between (41-50) and (51-60), and in favor of (51-60) where it reached an average arithmetic mean ( 5.00$)$, while the arithmetic average of the category (41-50) (4.68), no statistical significant differences appear between other cumulative rates. 
(Scheffe) test results Showed posterior Comparisons on areas according to the scientific qualification variable, with the following results (3):

- Differences in the area provide an effective framework for governance depending on the scientific qualification variable was between (diploma) and $(\mathrm{PhD})$, and in favor of $(\mathrm{PhD})$ where it reached an average arithmetic mean ( 5.00 ), while the arithmetic average of the class (diploma) (4.54), and did not show statisticalsignificant differences between the other cumulative rates.

- Differences in the area of availability of disclosure and transparency of systems depending on the scientific qualification variable was between (diploma) and (PhD), and in favour of (MS) where it reached an average ( 4.80 ), while the arithmetic mean of the class (diploma) (4.58), and did not show statistical significant differences between the other cumulative rates.

- Differences in the area of availability of regulations to control property system depending on the scientific qualification variable was between (diploma) and $(\mathrm{PhD})$, and in favor of $(\mathrm{PhD})$ where it reached an average mean ( 5.00 ), while the arithmetic average of the class (diploma) (4.54), statistical significant differences did not show among other cumulative rates.

Differences in the area provide a system that guarantees the rights of clients depending on the scientific qualification variable was between (Master) and (PhD), and in favor of (MS) where it reached an average ( 4.81 ), while the arithmetic average of the class $(\mathrm{PhD})(4.56)$, and statistical significant differences did not show among other cumulative rates.

* (Scheffe) Comparisons on areas according to the variable functional level with the following results (Appendix 4:

- Differences in the area provide an effective framework for corporate governance according to the variable career level was between (Director) and (Executive Officer), and for ( manager) where it reached an average ( 4.89 ), while the arithmetic average of the category (Executive Officer) (4.53), statistical significant differences did not show among other cumulative rates.

- Differences in the area of availability of disclosure and transparency of systems according to the variable career level was between ( Head ) and (Executive Officer), and in favor of ( Head) where it reached an average ( 4.77 ), while the arithmetic average of the category (Executive Officer) (4.64) did not show statisticalsignificant differences between the other cumulative rates.

- Differences in the area provide a system that guarantees the rights of clients depending on the variable career level was between ( Director ) and (Executive Officer), and for ( manager) where it reached an average ( 4.78 ), while the arithmetic average of the category (Executive Officer) (4:52), statistical significant differences between the other cumulative rates did not appear.

* (Scheffe) posteriori Comparisons on areas depending on the experience variable with the following results (Appendix 5):

- Differences in the area provide an effective framework for corporate governance according to the experience variable was between (6-10) and (16-20), and in favor (16-20) where it reached an average of ( 4.77 ), while the arithmetic mean of the class (6-10) (4.61), no statistical significant differences appear between other cumulative rates.

- Differences in the area of availability of disclosure and transparency of systems according to the experience variable was between (less than 5) and (6-10) in favor of ( less than 5) where it reached an average ( 4.70 ), while the arithmetic mean of the class (6-10) (4.67), no statistical significant differences showed between other cumulative rates.

- Differences in the area of availability of regulations to control property system according to the experience variable was between (less than 5) and (11-15), and in favor (11-15) where it reached an average ( 4.78 ), while the arithmetic mean of the category (less of 5) (4.63), no statistical significant differences appear between other cumulative rates.

- Differences in the area of availability of the system ensures that the rights of clients depending on the experience variable was between (less than 5) and (16-20), and in favor (16-20) where it reached an average ( 4.83 ), while the arithmetic mean of the category (less than 5) (4.56), no statistical significant differences appear between other cumulative rates.

The analysis of variance( ANOVA ) was applied To detect differences between the averages in the measure " the impact of commitmenting the sharing of time companies applying the standards of governance in creating 
permanent jobs in Jordan" as a whole depending on the variables (age, educational qualification, career level, experience), and (Table 7) shows that.

Table 7. Results of analysis of variance ( ANOVA ) To detect differences in the effect of commitmenting the sharing of timecompanies applying corporate governance standards in the creation of permanent jobs in Jordan "as a whole depending on the variables (age, educational qualification, career level, experience)

\begin{tabular}{lllllll}
\hline variable & $\begin{array}{l}\text { Sum } \\
\text { squares }\end{array}$ & $\begin{array}{l}\text { of } \\
\text { freedom }\end{array}$ & $\begin{array}{l}\text { Degrees } \\
\text { freed }\end{array}$ & $\begin{array}{l}\text { Average } \\
\text { squares }\end{array}$ & Values "F" & $\begin{array}{l}\text { Connotation } \\
\text { "F" } \\
\text { Statistical }\end{array}$ \\
\hline Age & $\mathbf{0 . 3 9 3}$ & $\mathbf{3}$ & $\mathbf{. 0 1 3 1}$ & $\mathbf{1 3 . 6 2 5}$ & $\mathbf{0 . 0 0 0}$ \\
Qualification & $\mathbf{0 . 0 7 9}$ & $\mathbf{3}$ & $\mathbf{0 . 0 2 6}$ & $\mathbf{2 . 7 2 0}$ & $\mathbf{0 . 0 5 0}$ \\
Career Level & $\mathbf{0 . 1 0 8}$ & $\mathbf{3}$ & $\mathbf{0 . 0 3 6}$ & $\mathbf{3 . 7 5 7}$ & $\mathbf{0 . 0 1 4}$ \\
Experience & $\mathbf{0 . 0 2 9}$ & $\mathbf{3}$ & $\mathbf{. 0 1 0}$ & $\mathbf{0 . 9 9 2}$ & $\mathbf{0 . 4 0 1}$ \\
The error & $\mathbf{0 . 7 1 2}$ & $\mathbf{7 4}$ & $\mathbf{. 0 1 0}$ & & \\
Total debugger & $\mathbf{1 . 9 7 6}$ & $\mathbf{8 6}$ & & & \\
\hline
\end{tabular}

- There were no statistical significant differences at the level of significance ( $A \leq 0.05)$ In the effect of commitmenting time sharing companies applying corporate governance standards in the creation of permanent jobs in Jordan, according to the experience variable, where it did not reach the value of " F "The level of statistical significance.

No statisticalsignificant differences at the level of significance ( $A \leq 0.05)$ In the effect of commitmenting time sharing companies applying corporate governance standards in the creation of permanent jobs in Jordan, according to the age variable as the value of (F ) (13.625) and in terms of statistical $(0.000)$.

No statistical significant differences at the level of significance ( $\mathrm{A} \leq 0.05)$ In the effect of commitmenting time sharing companies applying corporate governance standards in the creation of permanent jobs in Jordan, according to the scientific qualification variable as the value of ( F ) (2.720) and in terms of statistical $(0.050)$.

- No statistical significant differences at the level of significance ( $\mathrm{A} \leq 0.05)$ In the effect of commitmenting time sharing companies applying corporate governance standards in the creation of permanent jobs in Jordan, according to the variable functional level where the value of ( F ) (3.757) and in terms of statistical (0.0.014).

- To find out the differences in the areas as a whole, a( Scheffe ) tool was applied depending on the variables (age, educational qualification, career level), Comparisons dimensionality, and the tables below illustrate this:

* (Scheffe) posterior Comparisons on areas depending on the age variable with the following results (Appendix 6):

Differences in the instrument as a whole depending on the variable age was between (20-30) and (51-60), and in favor of ( 51-60) where it reached the average ( 4.92 ), while the arithmetic mean of the class (20-30) (4.60), statistical significant differences between the other cumulative rates did not show.

*(Scheffe) posterior Comparisons on areas according to the variable scientific qualification with the following results (Appendix 7:

Differences in the instrument as a whole depending on the scientific qualification variable was between (diploma) and $(\mathrm{PhD})$, and in favor of (MS) where it reached an average (4.83), while the arithmetic mean of the class (diploma) (4.57), no significant differences show statistical among other cumulative rates.

*(Scheffe) posterior Comparisons on areas according to the variable functional level withthe following results (Appendix 8):

- $\quad$ Differences in the instrument as a whole according to the variable career level was between (Director) and (Executive Officer), and for ( manager) where it reached an average ( 4.78 ), while the arithmetic

average of the category (Executive Officer) (4.56), no significant differences appear statistically among other cumulative rates.

\section{Results}

Based on statistical analysis, it showed that the results of a large impact to commitment the sharing of time, companies applying corporate governance in creating sustainable employment opportunities in Jordan in four 
areas related to the test questions, and also showed a statistical difference between the cumulative rates of all areas and related variables Profile of a sample of the respondents.

\section{Recommendations}

Based on the results of previous study, we recommend the following:

- To encourage this investment sector by the authorities concerned due to its great contribution to the creation of permanent jobs.

- The consolidation of the values and principles of governance in this type of companies (sharing time companies) because of its strong impact in the creation of permanent jobs.

- Follow - up and close monitoring to ensure the integrity of the application of the values and principles of governance in the time - sharing companies to ensure better job creation results.

- We recommend that time-sharing companies provide an effective framework for the governance of timesharing companies that contribute to the creation of permanent employment opportunities?

- We recommend that time-sharing companies provide systems of disclosure and transparency in time-sharing companies that contribute to the creation of permanent employment opportunities?

- We recommend that time-sharing companies provide regulatory rules to control the ownership system of time- sharing companies that contribute to the creation of permanent jobs?

- We recommend that time-sharing companies provide a system that guarantees the rights of customers in time- sharing companies that contribute to the creation of permanent jobs?

\section{References}

Abd, A. K., \& Nariman. (1999). The tourist Hotel legislation, Tourist Companies, Legal Counselling Tourism Organization. Sharing Time System at Egypt, Cairo, Arabic Renaissance house.

Abdullah, K. (2010). Doctor of Philosophy in Accounting, auditing science - theory (4th ed.).

Adel, A. (2011). A proposed model to measure governance and its impact on the credibility of information accounting gap. Amman Arab University, Amman, Jordan. Retrieved from https://www.researchgate.net/...11.../data/.../albhth-mdl-nhayy-fjwt-altwqat-2-11-2013

Al Sartawy, A. (2015). The impact of corporate governance on the performance of listed companies in the markets of financial states of the Gulf Cooperation Council.

Al, S., \& Abdel, H. (2013). Timeshare between the Islamic perspective and contemporary application. Journal of the Islamic Consciousness.

Alqashi, D. (2011). The ability of external auditors to audit the accounts of Jordanian companies dealing in e commerce. The University of the Middle East, Jordan. Retrieved from http://alqashi.com/th/th2.pdf

Atwi, F. (2004). Tourism legislation and tourism and hotels in Lebanon and the Arab countries. Al - Halabi human rights publications.

Azmi, J. (2012). The role of corporate governance in raising the competitiveness of Kuwaiti companies, unpublished search Master, the University of the Middle East Graduate Studies, Amman, Jordan. Retrieved from_https://meu.edu.jo/libraryTheses/586cc6f9eec25_1.pdf

Baloot, R. M. (2015). Master Thesis, the effects of the time - sharing contract, the Middle East University, Jordan. Retrieved from https://meu.edu.jo/libraryTheses/5879eace8050c_1.pdf

Emerson, P. (2005). Resale Timeshare.

Hammadi, N. (2012). The impact of the adoption of Algerian institutions to review the quality of governance on the financial: An Empirical Study. Algeria, Research and Scientific Studies Journal.

Ismail, A. A., \& Al-Jaber, A. H. A. (2010). The relationship between the actual application of corporate governance and the quality of financial reporting level, Middle East University, Jordan. Retrieved from https://9alam.com/community/threads/67-rsal-magstir-mxhasb-bgamy- alrdn.32163/

Mahasneh, N. (2006). Sharing Time contract (Timeshare) a Legal study, Jordanian Laws Comparison. The Private Law Department, College of Law, Yarmouk University, Irbid, Jordan._Retrieved from http://journals.yu.edu.jo/ayhss/Issues/vo23no3_2007.pdf 


\section{Appendixes}

Appendix 1. Arithmetic averages and standard deviations of the effect of commitmenting time sharing companies applying corporate governance standards in the creation of permanent jobs in Jordan due to variables (age, educational qualification, career level, experience)

\begin{tabular}{|c|c|c|c|c|c|}
\hline Area & Variables & Category & Number & SMA & standard deviation \\
\hline The area & Age & $20-30$ & 25 & $4: 55$ & 0.14 \\
\hline provides an & & $31-40$ & 23 & 4.59 & 0.21 \\
\hline effective & & $41-50$ & 27 & 4.79 & 0.17 \\
\hline framework & & $51-60$ & 12 & 4.93 & 0.09 \\
\hline for & Qualification & diploma & 24 & 4.54 & 0.17 \\
\hline \multirow[t]{14}{*}{ governance } & & Bachelor & 48 & 4.69 & 0.20 \\
\hline & & M.A. & 12 & 4.90 & 0.07 \\
\hline & & Doctorate & 3 & 5.00 & 0.00 \\
\hline & Career Level & Director & 24 & 4.89 & 0.12 \\
\hline & & Assistant & 17 & 4.65 & 0.27 \\
\hline & & Director & & & \\
\hline & & Head of the & 23 & 4.67 & 0.10 \\
\hline & & Department & & & \\
\hline & & Executive & 23 & 4.53 & 0.17 \\
\hline & & Officer & & & \\
\hline & Experience & Less than 5 & 19 & 4.57 & 0.11 \\
\hline & & $6-10$ & 29 & 4.61 & 0.19 \\
\hline & & $11-15$ & 18 & 4.83 & 0.13 \\
\hline & & $16-20$ & 21 & 4.77 & 0.27 \\
\hline The area of & Age & $20-30$ & 25 & 4.61 & 0.25 \\
\hline availability & & $31-40$ & 23 & 4.67 & 0.24 \\
\hline of disclosure & & $41-50$ & 27 & 4.71 & 0.13 \\
\hline and & & $51-60$ & 12 & 4.83 & 0.21 \\
\hline transparency & Qualification & diploma & 24 & 4.58 & 0.28 \\
\hline \multirow[t]{14}{*}{ of systems } & & Bachelor & 48 & 4.71 & 0.19 \\
\hline & & M.A. & 12 & 4.80 & 0.13 \\
\hline & & Doctorate & 3 & 4.70 & 0.00 \\
\hline & Career Level & Director & 24 & 4.63 & 0.30 \\
\hline & & Assistant & 17 & 4.73 & 0.08 \\
\hline & & Director & & & \\
\hline & & Head of the & 23 & 4.77 & 0.19 \\
\hline & & Department & & & \\
\hline & & Executive & 23 & 4.64 & 0.19 \\
\hline & & Officer & & & \\
\hline & Experience & Less than 5 & 19 & 4.70 & 0.19 \\
\hline & & $6-10$ & 29 & 4.67 & 0.24 \\
\hline & & $11-15$ & 18 & 4.70 & 0.06 \\
\hline & & $16-20$ & 21 & 4.69 & 0.30 \\
\hline The area of & Age & $20-30$ & 25 & 4.66 & 0.22 \\
\hline availability & & $31-40$ & 23 & 4.56 & 0.25 \\
\hline of & & $41-50$ & 27 & 4.75 & 0.17 \\
\hline regulations & & $51-60$ & 12 & 4.95 & 0.10 \\
\hline to control & Qualification & diploma & 24 & 4.54 & 0.25 \\
\hline property & & Bachelor & 48 & 4.73 & 0.20 \\
\hline \multirow[t]{6}{*}{ system } & & M.A. & 12 & 4.83 & 0.14 \\
\hline & & Doctorate & 3 & 5.00 & 0.00 \\
\hline & Career Level & Director & 24 & 4.82 & 0.16 \\
\hline & & Assistant & 17 & 4.68 & 0.20 \\
\hline & & Director & & & \\
\hline & & Head of the & 23 & 4.74 & 0.17 \\
\hline
\end{tabular}




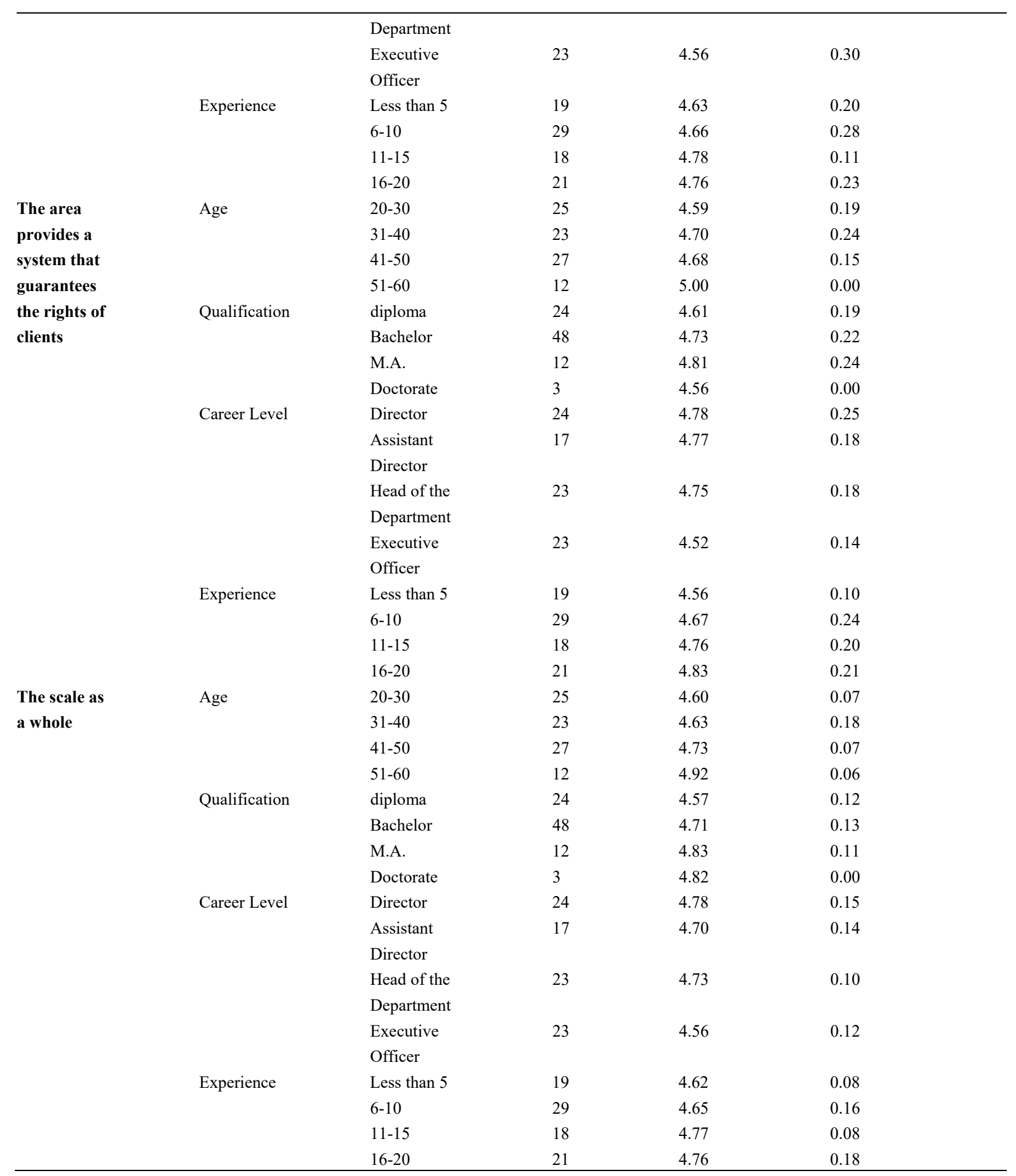


Appendix 2. Test results (Scheffe) posterior Comparisons on areas depending on the age variable

\begin{tabular}{|c|c|c|c|c|c|c|}
\hline Area & Age & SMA & $20-30$ & $31-40$ & $41-50$ & $51-60$ \\
\hline The area provides & 20-30 & $4: 55$ & - & Were 0.04 & $0.24-$ & $0: 38 * *$ \\
\hline an effective & $31-40$ & 4.59 & & - & $0.2-$ & 0.34 \\
\hline framework for & $41-50$ & 4.79 & & & - & 0.14 \\
\hline governance & $51-60$ & 4.93 & & & & - \\
\hline The area of & 20-30 & 4.61 & - & 0.06- & -0.1 & 0.22 \\
\hline availability of & $31-40$ & 4.67 & & - & Were 0.04 & $0: 16 * *$ \\
\hline $\begin{array}{ll}\text { disclosure } & \text { and } \\
\text { transparency } & \text { of }\end{array}$ & $41-50$ & 4.71 & & & - & 0.12 \\
\hline systems & $51-60$ & 4.83 & & & & - \\
\hline The area of & 20-30 & 4.66 & - & $0.1 * *$ & $0.09-$ & 0.29 \\
\hline availability of & $31-40$ & 4.56 & & - & $0.19-$ & $0: 39$ ** \\
\hline control property & $41-50$ & 4.75 & & & - & 0.2 \\
\hline system & $51-60$ & 4.95 & & & & - \\
\hline The area provides a & 20-30 & 4.59 & - & $0.11-$ & 0.09- & 0.41 \\
\hline system that & $31-40$ & 4.70 & & - & $0.02 * *$ & 0.3 \\
\hline guarantees & $41-50$ & 4.68 & & & - & $0: 32 * *$ \\
\hline rights of clients & $51-60$ & 5.00 & & & & - \\
\hline
\end{tabular}

Appendix 3. Test results (Scheffe) posterior Comparisons on areas depending on the scientific qualification variable

\begin{tabular}{|c|c|c|c|c|c|c|}
\hline Area & Qualification & SMA & diploma & Bachelor & M.A. & Doctorate \\
\hline \multirow{4}{*}{$\begin{array}{l}\text { The area provides an } \\
\text { effective framework } \\
\text { for governance }\end{array}$} & diploma & 4.54 & - & $0.15-$ & 0.36 & $0: 46 * *$ \\
\hline & Bachelor & 4.69 & & - & 0.21 & 0.31 \\
\hline & M.A. & 4.90 & & & - & $0.1^{* * *}$ \\
\hline & Doctorate & 5.00 & & & & - \\
\hline \multirow{4}{*}{$\begin{array}{lr}\text { The area } & \text { of } \\
\text { availability } & \text { of } \\
\text { disclosure } & \text { and } \\
\text { transparency } & \text { of } \\
\text { systems } & \end{array}$} & diploma & 4.58 & - & $0.13-$ & $0: 22 * *$ & 0.12 \\
\hline & Bachelor & 4.71 & & - & 0.09 & 0.01 \\
\hline & M.A. & 4.80 & & & - & $0.1^{* *}$ \\
\hline & Doctorate & 4.70 & & & & - \\
\hline \multirow{4}{*}{$\begin{array}{l}\text { The area of } \\
\text { availability of } \\
\text { regulations to control } \\
\text { property system }\end{array}$} & diploma & 4.54 & - & 0.19- & 0.29- & $0: 46 * *$ \\
\hline & Bachelor & 4.73 & & - & -0.1 & 0.27 \\
\hline & M.A. & 4.83 & & & - & 0.17 \\
\hline & Doctorate & 5.00 & & & & - \\
\hline \multirow{4}{*}{$\begin{array}{l}\text { The area provides a } \\
\text { system that guarantees } \\
\text { the rights of clients }\end{array}$} & diploma & 4.61 & - & $0.12-$ & $0.2-$ & 0.05 \\
\hline & Bachelor & 4.73 & & - & 0.08- & 0.17 \\
\hline & M.A. & 4.81 & & & - & $0.25 * *$ \\
\hline & Doctorate & 4.56 & & & & - \\
\hline
\end{tabular}


Appendix 4. Test results (Scheffe) posterior Comparisons on areas according to the variable career level

\begin{tabular}{|c|c|c|c|c|c|c|}
\hline Area & Career Level & SMA & Director & $\begin{array}{l}\text { Assistant } \\
\text { Director }\end{array}$ & $\begin{array}{l}\text { Head of the } \\
\text { Department }\end{array}$ & $\begin{array}{l}\text { Executive } \\
\text { employee }\end{array}$ \\
\hline \multirow[b]{2}{*}{$\begin{array}{l}\text { The area provides } \\
\text { an effective }\end{array}$} & Director & 4.89 & - & 0.24 & 0.22 & $0.36 * *$ \\
\hline & Assistant Director & 4.65 & & - & $0.02-$ & 0.12 \\
\hline $\begin{array}{l}\text { framework for } \\
\text { governance }\end{array}$ & $\begin{array}{l}\text { Head of the } \\
\text { Department }\end{array}$ & 4.67 & & & - & 0.14 \\
\hline \multirow{5}{*}{$\begin{array}{lr}\text { The area } & \text { of } \\
\text { availability } & \text { of } \\
\text { disclosure and } \\
\text { transparency }\end{array}$} & Executive Officer & 4.53 & & & & - \\
\hline & Director & 4.63 & - & -0.1 & $0.14-$ & 0.01 \\
\hline & Assistant Director & 4.73 & & - & Were 0.04 & 0.09 \\
\hline & $\begin{array}{l}\text { Head of the } \\
\text { Department }\end{array}$ & 4.77 & & & - & $0.13 * *$ \\
\hline & Executive Officer & 4.64 & & & & - \\
\hline \multirow{4}{*}{$\begin{array}{l}\text { The area provides } \\
\text { a system that } \\
\text { guarantees the } \\
\text { rights of clients }\end{array}$} & Director & 4.78 & - & 0.01 & 0.03 & $0: 26 * *$ \\
\hline & Assistant Director & 4.77 & & - & 0.02 & 0.25 \\
\hline & $\begin{array}{l}\text { Head of the } \\
\text { Department }\end{array}$ & 4.75 & & & - & 0.23 \\
\hline & Executive Officer & 4.52 & & & & - \\
\hline
\end{tabular}

Appendix 5. Test results (Scheffe) posterior Comparisons on areas depending on the experience variable

\begin{tabular}{|c|c|c|c|c|c|c|}
\hline Area & Experience & SMA & diploma & Bachelor & M.A. & Doctorate \\
\hline \multirow[t]{4}{*}{ The area provides an effective framework for governance } & Less than 5 & 4.57 & - & 0.04 & $0.26-$ & $0.2-$ \\
\hline & $6-10$ & 4.61 & & - & $0.22-$ & $0: 16-* *$ \\
\hline & $11-15$ & 4.83 & & & - & 0.06 \\
\hline & $16-20$ & 4.77 & & & & - \\
\hline \multirow[t]{4}{*}{ The area of availability of disclosure and transparency of systems } & Less than 5 & 4.70 & - & $0.03 * *$ & 0 & 0.01 \\
\hline & $6-10$ & 4.67 & & - & -0.03 & -0.02 \\
\hline & $11-15$ & 4.70 & & & - & 0.01 \\
\hline & $16-20$ & 4.69 & & & & - \\
\hline \multirow[t]{4}{*}{ The area of availability of regulations to control property system } & Less than 5 & 4.63 & - & -0.03 & $0.15-* *$ & $0.13-$ \\
\hline & $6-10$ & 4.66 & & - & $0.12-$ & -0.1 \\
\hline & $11-15$ & 4.78 & & & - & 0.02 \\
\hline & $16-20$ & 4.76 & & & & - \\
\hline \multirow[t]{4}{*}{ The area provides a system that guarantees the rights of clients } & Less than 5 & 4.56 & - & $0.11-$ & $0.2-$ & $0: 27$ - ** \\
\hline & $6-10$ & 4.67 & & - & $0.09-$ & $0.16-$ \\
\hline & $11-15$ & 4.76 & & & - & $0.07-$ \\
\hline & $16-20$ & 4.83 & & & & - \\
\hline
\end{tabular}

Appendix 6. Test results (Scheffe) posterior Comparisons on areas depending on the age variable

\begin{tabular}{llllll}
\hline The tool as a whole & SMA & $\mathbf{2 0 - 3 0}$ & $\mathbf{3 1 - 4 0}$ & $\mathbf{4 1 - 5 0}$ & $\mathbf{5 1 - 6 0}$ \\
\hline $\mathbf{2 0 - 3 0}$ & 4.60 & - & $0.03-$ & $0.13-$ & $0.1-* *$ \\
$\mathbf{3 1 - 4 0}$ & 4.63 & - & - & $0.29-$ \\
$\mathbf{4 1 - 5 0}$ & 4.73 & & & $-19-$ \\
$\mathbf{5 1 - 6 0}$ & 4.92 & & & - \\
\hline
\end{tabular}


Appendix 7. Test results (Scheffe) posterior Comparisons on areas depending on the scientific qualification variable

\begin{tabular}{llllll}
\hline The tool as a whole & SMA & diploma & Bachelor & M.A. & Doctorate \\
\hline diploma & 4.57 & - & $0.14-$ & $\mathbf{0 : 2 6 - * *}$ & $0.25-$ \\
Bachelor & 4.71 & & - & $0.12-$ & $0.11-$ \\
M.A. & 4.83 & & & - & 0.01 \\
Doctorate & 4.82 & & & - \\
\hline
\end{tabular}

Appendix 8. Test results (Scheffe) Posteriori Comparisons on areas according to the variable career level

\begin{tabular}{llllll}
\hline The tool as a whole & SMA & $\begin{array}{l}\text { Director } \\
\text { Director }\end{array}$ & Assistant & $\begin{array}{l}\text { Head of } \\
\text { Department }\end{array}$ & theExecutive Officer \\
\hline Director & 4.78 & - & 0.08 & 0.05 & $0: 22 * *$ \\
Assistant & 4.70 & - & & $0.03-$ & 0.14 \\
$\begin{array}{l}\text { Director } \\
\text { Head of the }\end{array}$ & 4.73 & & & - & 0.17 \\
$\begin{array}{l}\text { Department } \\
\text { Executive Officer }\end{array}$ & 4.56 & & & & - \\
\hline
\end{tabular}

\section{Copyrights}

Copyright for this article is retained by the author(s), with first publication rights granted to the journal.

This is an open-access article distributed under the terms and conditions of the Creative Commons Attribution license (http://creativecommons.org/licenses/by/4.0/). 